\title{
ANALISIS QUR'AN SURAH AL-QURAISY TENTANG ETOS KERJA
}

\author{
Muhammad Thariq Aziz \\ E-mail : thariq@ummi.ac.id \\ Lembaga Al-Islam dan Kemuhammadiyahan \\ Universitas Muhammadiyah Sukabumi
}

\begin{abstract}
Abstrak
Etos kerja merupakan aspek penting dalam peningkatan kualitas kerja yang merupakan bagian dari ibadah. Allah telah memberikan contoh melalui ayat-ayat qauliyahNya dalam bentuk sejarah sebagai kajian dan renungan bagi umat yang akan datang. Dalam aspek etos kerja Allah telah menurunkan satu surah yang dapat menjadi acuan untuk peningkatkan etos kerja. Penelitian ini berusaha untuk menganalisis etos kerja kaum Qurais sehingga menjadi kaum yang istimewa. Penelitian ini adalah penelitian literatur dengan menggali sebanyak mungkin informasi dari al-Qur'an \& hadits terkhusus surah al-Quraisy dan pendapat para pakar dalam etos kerja. Hasil penelitian ini menunjukkan bahwa dalam surah al-Quraisy Allah telah memberikan pedoman yang sangat singkat dan padat dalam persoalan etos kerja, jika pedoman ini mampu dijalankan dengan baik maka dapat membawa kemakmuran bagi peseorangan, masayarakat atupun negara.
\end{abstract}

Kata Kunci : al-quraisy, etos kerja, kaum qurais 
PENDAHULUAN

$\mathrm{M}$

anusia merupakan makhluk

Allah dengan tugas

ciptaan

khalifah di muka bumi.

Allah menunjuk manusia sebagai khalifah dimuka bumi bukan tanpa sebab namun karena manusia merupakan makhluk Allah dengan kemampuan yang lebih dibandingkan dengan makhluk yang lain. Manusia tercipta dengan banyak kelebihan, kelebihan yang tidak dimiliki oleh makhluk lain adalah akal.

Akal yang telah diberikan oleh Allah berfungsi untuk menaklukkan alam seisinya bukan sebatas mengekploitasi namun dengan tujuan merawat dan memenuhi kebutuhan hidupnya. Dalam proses memenuhi kebutuhan tersebut maka manusia bekerja. Proses bekerjanya manusia berbeda dengan bekerjanya makhluk ciptaan Allah yang lain.

Mengambil ungkapan Prof. Dr Hamka "Kalau hidup sekedar hidup babi di hutan juga hidup, kalau bekerja sekedar bekerja kera juga bekerja". 1 Ungkapan tersebut memberikan ilustrasi bagaimana seharusnya manusia menjalani proses kehidupannya sesuai dengan perintah dari Allah, begitu juga dengan proses bekerja seorang manusia. Manusia tidak boleh bekerja hanya sebatas bekerja tanpa ada tujuan yang jelas dan tidak sesuai dengan perintah sang pencipta. Bekerjanya manusia adalah salah satu wujud ibadah muamalah sebagaimana di jelaskan dalam al-Qur'an "dan bahwa manusai hanya memeperoleh apa yang telah diusahakan, dan sesungguhnya usahanya itu kelak akan dipersliahtakn, kemudian akan diberi balasan kepadanya dengan balasan yang paling sempurna, dan sesungguhnya kepada tuhanmulah kesudahannya segala sesuatu (Q.S an-Najm : 39-42)". 2

Sebagai seorang yang beriman kepada Allah maka tidak boleh bermalas-malasan dalam bekerja karena Allah akan memberikan balasan kepada orang yang mau bekerja dengan dilandasi iman dan niat beribadah berlipat dan sempurna. Hal ini dapat dilihat bagaimana kaum Quraisy bekerja dan beribadah kepada tuhannya pada masa lalu, sehingga Allah mengabadikan dalam salah satu Surah di Al-Qur'an yakni Surah al-Quraisy, Surah yang ke 106. Asbabun nuzul Surah Al-Quraisy adalalah salah satu balasan Allah mengangkat derajat kaum Quraisy atas segala yang telah mereka perbuat sebagai ibrah atau pelajaran bagi kaum setelahnya.

Berdasarkan latar belakang diatas penelitian ini bermaksud untuk mengungkap kehebatan kaum Quraisy dalam bekerja yang memiliki etos yang baik sehngga Allah mengangkat derajatnya. Penelitian ini bertujuan agar etos kerja kaum Quraisy dapat diterapkan dalam proses kerja kaum muslim saat ini suapaya dapat survive dalam mengarungi kehidupan baik di dunia maupun di akhirat sesuai dengan perintah Allah sang pencipta.

\section{PEMBAHASAN}

\section{Etos Kerja}

Etos Kerja terdiri dari dua kosa kata yakni etos dan kerja. Etos secara etimologi berasal dari bahasa Yunani "Ethos" berarti tempat hidup. Perkembangan makna pun tidak dapat dipungkiri dengan berjalannya waktu kata etos mengalami pergeseran menjadi watak atau karakteristik, selain itu muncul istilah Ethikos yang berarti teori 
kehidupan kemudian berevolusi menjadi etika. Makna karakter ini senada dengan makna etos dalam bahasa Inggris character.

Aristoteles menggambarkan etos sebagai salah satu dari tiga mode persuasi selain logos dan pathos Ia juga mengartikannya sebagai kompetensi moral. Namun Aristoteles berusaha memperluas makna istilah ini hingga keahlian dan pengetahuan tercakup didalamnya. Ia menyatakan bahwa etos hanya dapat dicapai hanya dengan apa yang dikatakan seorang pembicara, tidak dengan apa yang dipikirkan orang tentang sifatnya sebelum ia mulai berbicara.

Secara sederhana etos adalah sifat atau karakter individu ada sekelompok manusia yang lahir melalui kebiasaan guna mencapai suatu tujuang dengan disertai semangat yang tinggi. Sehingga dengan menggunakan etos seseorang atau sekelompok manusia dapat mencapai tujuan yang diharapkan denagn lebih efektif dan efisien.

Sementara kerja secara bahasa berarti melakukan suatu kegiatan. ${ }^{3}$ Kerja adalah suatu usaha yang dilakukan seseorang, baik sendiri atau bersama orang lain, untuk

memproduksi suatu komoditi atau memberikan jasa. Sedangkan menurut Toto Tasmara, kerja adalah suatu upaya yang sungguh-sungguh, dengan mengerahkan seluruh aset, pikir, dan zikirnya untuk mengaktualisasikan atau menampakkan arti dirinya sebagai hamba Allah yang harus menundukkan dunia dan menempatkan dirinya sebagai bagian dari masyarakat yang terbaik (khairul ummah). ${ }^{4}$

Dalam arti sempit kerja berkonotasi ekonomi yang bertujuan mendapatkan materi, sedangkan dalam arti luas kerja mencakup semua bentuk usaha yang dilakukan manusia baik terkait dengan materi atuapun non materi, bersifat fisik atauun noni fisik. Secara hakiki kerja merupakan bagian dari ibadah muamalah yang dilakukan manusia berunsur kebaikan dan keberkahan bagi diri sendiri dan orang yanga ada disekitarnya serta sebagai wujud dalam mengikuti perintah allah untuk mendapatkan bekal keidupan dunia ataupun kehidupan akhirat.

Berdasarkan uraian diatas etos kerja dapat dipahamai menjadi suatu kehendak mausia atau kemeuan untuk bekerja yang disertai dengan semangat tingg untuk mewujudkan tujuan yang akan dicapai. Dapat juga dipahami bahwa etos kerja merupakan sikap seseorang yang sangat mendasar tentang kerja, yang merupakan cerminan dari pandangan hidup yang berorientasi dari nilai-nilai ketuhanan (ilahiyah) atau pancaran dari sikap hidup manusia yang mendasar terhadap kerja.

\section{Surah Al-Quraisy}

Surah al-Quriasy adalah Surah ke 106 dalam al-Qur'an, di antara surah al-fil dan surah al-ma'un. Munasabah surah al-fill dengan al-Quraisy terletak perlindungan ka'bah dari penghancuran oleh pasukan gajah. Sedangkan munasabah antara surah al-Quraisy dengan surah al-Ma'un terletak pada pembebasan manusai dari kelaparan dan perintah untuk menyembah Allah dan tidak boleh lalai dalam menyembahnya.

Surah al-Quraisy masuk kategori surah makiyyah, bukan hanya karena turun di makkah namun juga sasaran yang dituju dalam suart-Surah makiyyah berupa ajakna tauhid \& ibadah kepada Allah, dasar-dasar perundangan dan akhlak dalam rangka 
pembentukan masyarakat serta berisi kisahkisah umat terdahulu sebagai pelajaran bagi umat sekarang. Walaupun secara urutan di al-Qur'an setelah surah al-Fill namun urutan turunnya kepada Rasulullah dalam bentuk wahyu setelah surah at-Tiin.

Asbabun nuzul surah ini berdasarkan hadits dari Ummu Hani binti Abu Thalib yang berkata "Rasulullah bersabda, Allah memberikan keistimewaan kepada suku Quraisy dengan tujuh hal. Saya dijadikan berasal dari mereka, kenabian ada pada mereka, tugas menjga (Ka'bah) ada pada mereka, tugas memberi minum (Jama'ah haji) juga ada pada mereka, allah telah menyelamatkan mereka dari serangan tentara bergajah, mereka menyembah Allha tujuh tahun lamanya sementara tidak ada satu kaumpun yang menyembah Allah selama itu, dan sesungguhnya Allah telah menurunkan satu surah penuh dalam alQur'an yang hanya mereka yang disebut di dalamnya. stelah berkata demikina Rasulullah lantas membacakan ayat ini". 5 Terdapat kelibihan yang di berikan Allah kepada kaum Qurais yang tidak dimiliki oleh kaum lain bahkan hal tersebut masih berlaku hingga saat ini. Inilah keistimewaan yang di berikan Allah kepada kaum Qurais yang diabadikan dalam satu surah penuh.

Surah ini terdiri dari empat ayat. Nama Quraisy diambil dari kata Quraisy yang terdapat pada ayat pertama, artinya suku Qurais. Suku Qurais adalah suku mendiami Mekah. Qurais pada masa Nabi Muhammad merupakan kabilah terbesar yang paling terkenal dan berpengaruh di Mekah. Mereka yang memegang tampuk pimpinan di Mekah, termasuk mendapat kehormatan untuk memelihara Ka'bah sebagaimana dijelaskan pada hadits di atas.
Kabilah Qurais merupakan eponi yang diambil dari Quraisy, nama dari salah seorang leluhur mereka yang bernama Fihr. ${ }^{6}$ Namun hal ini ada beberapa pendapat antara nama asli dan nama julukan dari Fihr, yang merupakan keturuna dari Ismail dan Qahthan yang menjadi bapak bagi seluruh orang Arab.

\section{Etos kerja dalam Surah al-Quraisy}

Rasulullah telah menyebutkan dalam haditsnya betapa hebatnya kaum Qurais sehingga Allah mengabadikan secara khusus dalam satu surah penuh. Hal ini mengandung makna bahwa ada sesuatu yang hebat yang dapat diambil oleh umat Nabi Muhammad saat ini. Surah ini juga mengandung pedoman yang padat dibidang ekonomi terutama dalam etos kerja.

Etos kerja tinggi yang ditunjukkan kaum Qurais untuk mampu bertahan hidup dari gempuran zaman sangat patut dikaji sebagai bahan untuk dapat di ikuti oleh orang-orang saat ini. Hal ini tercantum dalam surah al-Quraisy diantaranya adalah kebiasaan positif, citra positif, mobilitas yang tinggi dan orientasi ibadah.

\section{a. Kebiasaan Positif}

Kebiasaan adalah sesuatu yang biasa dilakukan, kebiasaan juga berarti pola untuk melakukan tanggapan terhadap situasi tertentu yang dipelajari oleh seorang individu dan yang dilakukannya secara berulang untuk hal yang sama. ${ }^{7}$ Dapat dilihat ketika ada orang yang mengajak bersalaman maka secara spontan orang yang diajak mengulurkan tangan kanan terhadap orang yang mengajak bersalaman. Hal ini terjadi 
karena sudah menjadi kebiasaan bagi seseorang untuk melakukan hal tersebut yang sudah terlatih sejak kecil dan berulang-ulang yang akhirnya menjadi kebiasaan. Kebiasaan juga dapat diartikan sebagai respon seseorang dalam menghadapi suatu hal tanpa melalui proses berpikir. Kebiasaan dikatakan respon karena kebiasaan tidak melalui proses berpikir manusia secara otomatis melakukannya.

Kaum Qurais telah memiliki kebiasaan yang sangat baik sebagaimana terdapat dalam ayat pertama “شْيَرَف فلايلاٍ " yang artinya kebiasaan orang-orang Qurais. Dalam kajian bahasa arab "lam" pada awal ayat tersebut memiliki makna ta'jub atau keheranan. Keta'juban terhadap kebiasaan yang dilakukan oleh orang-orang Qurais, lalu kebiasaan apa yang membuat heran, ternyata kebiasan tersebut adalah berdagang.

Kebiasaan berdagang merupakan hal yang telah dihasilkan oleh orang-orang Qurais melalui proses latihan, didikan secara turun menurun, sehingga berdagang menjadi sebuah pengalaman yang sangat melekat bagi orangorang Qurais. Selain hal ini

pembiasaan berdagang sangat mempengrauhi kehidupan orang-orang Qurais baik pada masa lalu hingga pada masa nabi Muhammad, sebagaimana dapat dilihat dari hadits Rasulullah tentang berdagang sebagai berikut:

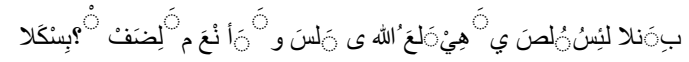

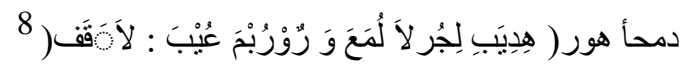

$$
\begin{aligned}
& \text { "Rasulullah SAW ditanya tentang }
\end{aligned}
$$
keutamaan harta, beliau menjawab setiap jual beli yang mabrur dan penghasilan seseorang dari jerih payah tangannya sendiri."
Berdasarkan hadits diatas menunjukkan jual beli atau berniaga merupakan kebiasaan yang positif yang dapat dilakukan oleh seseorang untuk mendapatkan harta yang utama atau dapat diartikan bahwa berdagang merupakan anjuran yang utama untuk mendapatkan harta yang baik. Berdagang inilah yang menjadi kebiasaan orang-orang Qurais sehingga mendapat keistimewaan dari Allah dan menjadi bahan pembelajaran bagi orang-orang yang ada setelahnya.

\section{b. Citra Positif}

Citra dapat didefinisikan sebagai gambaran mental atau konsep tentang sesuatu. Secara lebih luas citra dapat juga didefinisikan sebagai sejumlah keyakinankeyakinan, gambaran-gambaran, dan kesankesan yang dipunyai seseorang pada suatu obyek. ${ }^{9}$ Obyek yang dimaksud bisa berupa orang, organisasi, atau kelompok orang. Jika obyek itu sekelompok orang, berarti seluruh keyakinan, gambaran, dan kesan atas sekelompok orang dari orang lain merupakan citra.

Pada dasarnya citra adalah sesuatu yang abstrak (intangible), tidak nyata, tidak bias digambarkan secara fisik dan tidak dapat diukur secara matematis, karena citra hanya ada dalam pikiran. Namun wujudnya bisa dirasakan dari hasil penilaian baik atau buruk. Sebagaimana tanggapan positif maupun negatif yang datang dari publik pada umumnya.

Keistimewaan kaum Qurais adalah mampu membangun citra positif berpuluhpuluh tahun sehingga mereka menjadi kabilah yang paling mulia di antara kabilahkabilah yang lain di Mekah. Citra ini dibangun melalui proses perdagangan 
mereka. hal ini dapat dilihat pada ayat ke dua

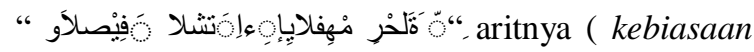
mereka bepergian pada musim dingin dan

musim panas). Melalui perjalanan perdangan inilah kaum Qurais membangun citra positif dalam berdagang dengan

menggunakan prisnip yang sesuai disampakan oleh Rasulullah

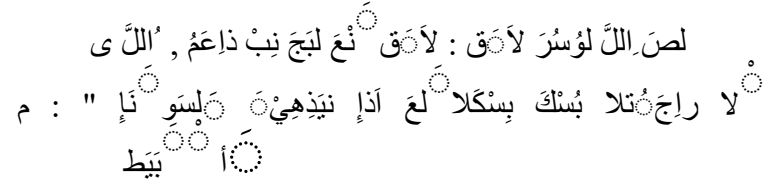

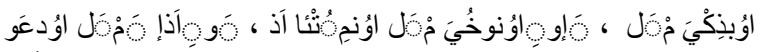

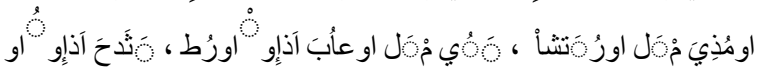

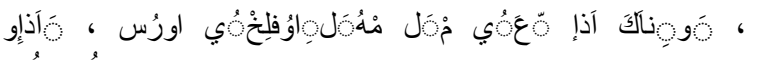

10

Dari Mu'adz bin Jabal, Rasulullah SAW

bersabda : Sesungguhnya sebaik-baik penghasilan ialah penghasilan para pedagang yang mana apabila berbicara tidak bohong, apabila diberi amanah tidak

khianat, apabila berjanji tidak mengingkarinya, apabila membeli tidak mencela, apabila menjual tidak berlebihan (dalam menaikkan harga), apabila berhutang tidak menunda-nunda pelunasan dan apabila menagih hutang tidak memperberat orang yang sedang kesulitan.

Dalam melakukan perdangangan yang sudah menjadi kebiasaan positif kaum Qurais menggunakan prinsip sebagaimana dalam hadits tersebut yakni apabila berbicara tidak bohong, apabila diberi amanah tidak khianat, apabila berjanji tidak mengingkarinya, apabila membeli tidak mencela, apabila menjual tidak berlebihan (dalam menaikkan harga), apabila berhutang tidak menunda-nunda pelunasan dan apabila menagih hutang tidak memperberat orang yang sedang kesulitan. Dan hal inilah yang menjadi citra positif kaum Qurais dikalangan pedagang dari kabilahkabilah yang di kunjungan dalam perjalan dagang. c. Mobilitas Tinggi

Mobilitas adalah proses gerak penduduk dari suatu wilayah menuju wilayah lain dalam jangka waktu tertentu. ${ }^{11}$ Mobilitas juga dapat diartikan pergerakan yang dilakukan seseorang atau banyak orang untuk melakukan kegiatan atau perpindahan dari satu wilayah ke wilayah lain.

Kaum Qurais pada masa itu melakukan proses dagang dengan mobilitas yang tinggi. Mereka mengadakan misi perdagangan ke luar daerahnya, bahkan sampai ke luar negeri. hal ini dapat dilihat pada surah al-Quraisy ayat 2 “

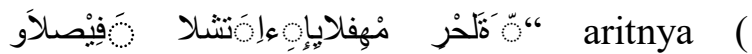
kebiasaan mereka bepergian pada musim

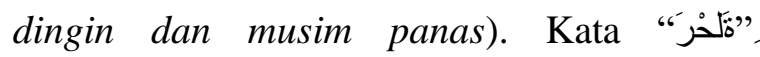
bepergian inilah yang menjadi kunci perdagangan kaum Qurais. Seorang pedagang tidak akan maju jika tidak mengadakan misi "rihlah" keluar daerahnya.

Prinsip yang di gunakan kaum Qurais ini menjadi salah satu kunci bagaimana seorang pedagang menjadi maju dan sukses. Misi perdagangan kaum Qurais dilakukan sepanjang musim yakni pada musim dingin ataupun pada musim panas. Pada musim dingin kaum Qurais melakukan perdagangan ke Selatan yakni ke negeri Yaman untuk membeli rempah-rempah yang datang dari timur jauh melalui Teluk Persia dan pada musim panas mereka pergi ke Utara yakni ke Syam untuk membeli hasil pertanian yang di bawa pulang ke Mekah. Hal ini di lakukan karena pada dasarnya daerah yang di diami oleh kaum Qurais merupakan daerah yang tandus sehingga tidak menghasilkan sumber pangan yang baik. 
d. Orientasi Ibadah

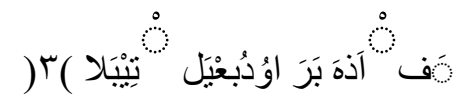

Artinya : Maka hendaklah mereka menyembah tuhan pemilik nama ini.

Etos kerja kaum Qurais berdasarkan ayat yang ke-3 adalah orientasi ibadah. Proses perdagangan yang dilakukan oleh orang-orang Qurais tidak hanya sebatas

melakukan perdagangan namun ada orientasi ibadah kepada tuhan. Ibadah yang dilakukan kaum Qurais bukan hanya sebatas mereka beribadah namun mereka juga melayani orang-orang yang melaksanakan ibadah di Mekkah.

Orientasi Ibadah ini berefek pada perdagangan mereka, dalam berdagang ke berbagai negara mereka mendapat keamanan. Orang-orang Badui yang dilalui untuk perdagangan sangat menghormati kaum Qurais dan mereka menjaga keamanan perjalanan tersebut karena kaum Qurais dipandang sebagai penduduk tanah suci dan berkhidmat dalam menjaga Ka'bah.

Rasa hormat terhadap baitullah inilah yang menjadi suatu kekuatan jiwa dan berwibawa untuk menjaga keselamatan dalam misi-misi perdagangannya baik ke Utara ataupun ke Selatan, sehingga timbullah kebiasaan dan kegemaran untuk berdagang yang manghasilkan banyak rejeki. Rasa hormat ke baitullah ini adalah kehendak Allah, seandainya bukan karena rasa hormat yang ditimbulkan dari jiwa orang-orang Arab maka tidak mungkin kaum Qurais mendapatkan keamanan dan kesejahteraan dalam rangka menjalankan misi-misi perdagangan mereka. Sehingga orientasi ibadahlah yang memberikan jalan untuk mendapatkan rezeki. Karena hanya Allah lah yang membuka pintu-pintu rezeki dan yang mampu memberi riski kepada siapa saja yang beribadah kepadanya dan meminta kepadanya. Hal ini dijelakan dalam ayat yang ke-4

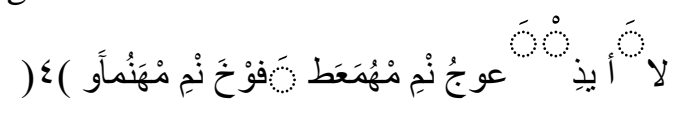

Artinya : Yang telah memberi makanan kepada mereka untuk menghilangkan lapar dan mengamakan mereka dari rasa ketakutan.

\section{SIMPULAN}

Surah al-Qurais ini mengandung pedoman yang sangat singkat dan padat dalam persoalan etos kerja, jika pedoman ini mampu dijalankan dengan baik maka dapat membawa kemakmuran bagi peseorangan, masayarakat ataupun negara. Melalui kemakmuran peseorangan dengan etos kerja yang baik maka akan mempercepat pembangunan masyarakat menuju masya-rakat yang mandiri dan berkemajuan.

Etos kerja tersebut adalah, memilki kebiasaan yang positif yakni perdagangan, membangun citra positif dalam segala aspek, mobilitas yang tinggi agar mampu membangun sebuah jaringan yang baik dan di akhiri dengan orientasi ibadah karena segala sesuatu yang dilakukan itu tidak lain adalah kehendak dari Allah sebagai Tuhan Alam semesta

\section{Daftar Rujukan}

Abdullah, Muhammad, Tafsir ibnu katsir jilid 10, Jakarta : Pustaka imam syafi'ai, 2012.
Al-Baihaqi , Syu'abul Iman, Bab Hifzhu Al- Lisan (IV/221). 
Al-Jauziy, Ibnu. Zâd al-Masîr. Kitab Digital Al-Maktabah al-Syamilah.

Al-Tobary, Abu Ja' far Muhammad Ibn Jarir. (310H). Jami' al-Bayan fi Ta'wil alQur'an. Kitab Digital al-Maktabah alSyamilah. Ar-Risalah.

Badan Diklat Kementrian Agama RI, Tafsir Al-Qur'an Tematika, Jakarta : Kamil Pustaka, 2014.

Depdikbud, Kamus Besar Bahasa Indonesia, Jakarta :1995.

Hamka, Falsafah Hidup, Memecahkan Rahasia Kehidupan Berdasarkan Tuntuan Al-Quran Dan As-Sunah, Jakarta : Republika, 2015.

Hamka, Tasawuf Modern, Bahagia Itu Dekat Dengan Kita Ada Di Dalam Diri Kita, Jakarta : Republika, 2015.

Kahlil al-Qattan, Manna'. Studi Ilmu-ilmu Qur'an.Jakarta : Litera Alam Nusa. Halim Jaya 2009.

Kasali, Renald, Change, Jakarta : PT Gramedia, 2010.

Kementrian Agama R.I, Al-Qur'an dan Tafsirnya, Jakarta:PT Sinergi Pustaka Indonesia,2012.
Satlita, Lena, Membangun Citra Positif Organisasi Melalui Public Relation, (Artikel).

Suharso dan Ana Retnoningsih, Kamus Besar Bahasa Indonesia, Semarang : CV. Widya Karya, 2009.

Tasmara, Toto, Membudayakan Etos Kerja Islami, Jakarta : Gema Insani, 2002.

Wahyuni' Sri, Studi tentang mobilitas penduduk di kelurahan sempaja selatan kecamatan samarinda utara kota samarinda, eJournal Ilmu Pemerintahan, 2 (1) 2014.

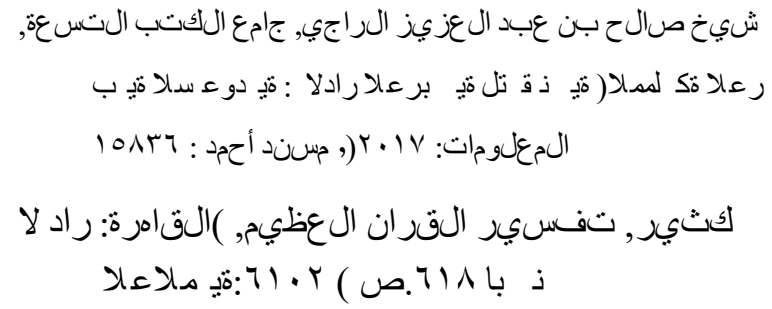


Muhammad Thariq Aziz - Analisis Qur'an Surah...

${ }^{1}$ Prof. Dr Hamka, Falsafah Hidup "Memecahkan Rahasi Sunah ”, ( Jakarta: Repulika, 2015)

${ }^{2}$ Departemen Agama RI, Al-Qur'an dan Terjemahnya, (Jakarta : Sygma Exagrafika, 2009), hlm.527

${ }^{3}$ Drs. Suharso dan Dra. Ana Retnoningsih, Kamus Besar Bahasa Indonesia, (Semarang:

CV. Widya Karya, 2009), cet. ke VIII, h. 242

${ }^{4}$ Toto Tasmara, Membudayakan Etos Kerja Islami, (Jakarta: Gema Insani, 2002), h. 25

5 ابن كثري, تفسري القران العظيم, )القاهرة: الدار العاملية:؟ • 17 ( ص.717 17

${ }^{6}$ Kementrian Agama R.I,

${ }^{7}$ Depdikbud, Kamus Besar Bahasa Indonesia, (Jakarta:1995). Hlm 129

8 شيخ صداحل بن عبد العزيز الراجي, جامع الكتب التسعة, )املمكة العربية السعودية : الدار العربية لتقنية املعلومات: ؟ •V|(, مسند أمحد :

1014r

${ }^{9}$ Lena Satlita, Membangun Citra Positif Organisasi Melalui Public Relation, (Artikel)

10 Al-Baihaqi, Syu'abul Iman, Bab Hifzhu Al-Lisan (IV/221).

${ }^{11}$ Sri Wahyuni, Studi Tentang Mobilitas Penduduk Di Kelurahan Sempaja Selatan Kecamatan S Kota Samarinda, (eJournal Ilmu Pemerintahan, 2 (1) 2014 : 1889-1901) 
Jurnal TAMADDUN - FAI UMG. Vol. XiX. No.1 / Januari 2018 